\title{
Průmyslové enzymy
}

\author{
JIR̆Í STÁRKA,
}

577.15

Oddělení obecné mikrobiologie biologické fakulty Karlovy university, Praha

\section{Enzymy bakterií, kvasinek a plísní - 2. část*)}

Mikrobiální enzymy maji mnoho možností uplatnění v technické praxi. Největší zájem je o plísňové a bakteriální amylázy; těmto enzymům byla věnována první část referátu [64]. Mikroorganismy jsou ovšem zdrojem téměř nepřehledné řady dalších enzymů, $\mathrm{z}$ nichž dosud jen některé byly studovány s praktickým aspektem. Souborné pojednání o těchto enzymech nedávno publikoval Hoogerheide [65]. Upozorníme proto jen na ty, které mají vztah $\mathrm{k}$ technické mikrobiologii a zejména ke kvasnému průmyslu.

Plísňové otruby (amylolytické) maji i poměrně značnou aktivitu proteolytickou. To platí zvláště o otrubách z Aspergilus oryzae. Podle našich pokusů $1 \mathrm{ml} 10 \%$ vodného extraktu přidaný $\mathrm{k} 5 \mathrm{ml} 2 \%$. kaseinové suspense rozloží $50 \%$ kaseinu za $60 \mathrm{~min}$. při mírně alkalickém $\mathrm{pH}$. Aspergilus niger je asi 10krát slabši. Silnou proteolytickou aktivitu maji i aktinomycety a byly ěiněny pokusy o využití jejich surového mycelia zbývajícího po fermentaci antibiotik.

Komerěně vyráběné proteázy jsou převážně bakteriálního původu (B. subtilis). Jejich př́prava je stejná opět jako u amyláz $[57,58]$. Proteázy jsou však méně stabilní než amylázy a jsou proto náročnější na konečné zpracování na technicky použitelný preparát. Nejvíce se používají v koželužství, $\mathrm{v}$ textilním průmyslu $\mathrm{k}$ odstraňování želatinových lepidel a $\mathbf{k}$ odstraňování skvrn $\mathbf{z}$ oděvů a čalounů. Že ani tato poslední aplikace není maličkostí, svědčí to, že v USA čini ročně částku 1000000 dolarů. Pro náš potravinářský průmysl je zvlášt významné užití proteáz $\mathrm{k}$ hydrolyse bílkovin $\mathbf{v}$ pivě, aby bylo zabráněno tvorbě zákalů během skladování. Vynikajícími producenty proteolytických enzymů jsou aktinomycety $[48,49]$ a plísně $[1,2,3,4]$, dokonce i Penicillium notatum [9]. Zvlášt vhodní jsou členové skupiny Aspergilus flavus oryzae, které lze kultivovat na pủdě se sojovou moukou $[5,6]$, a Aspergilus niger [34] nebo na otrubách [7]. Selekcí vhodných kmenů se zabývalo několik prací [53, 54]. Byl př̀ipraven i krystalický preparát z Aspergilus oryzae typu trypsinu [8].

Pektolytické enzymy $[41,42]$, t. j. pektinmethylesteráza a polygalakturonáza se připravují stejně jako amylázy bud' na lískách na otrubách (na př. německý Filtragol, produkt Aspergilus wentii a Aspergilus aureus), nebo submersně v. tancích na pektinových substrátech. Nejvhodnějš́ jsou penicilia a aspergily. Preparátů se užívá $\mathbf{k}$ čeření ovocných štáv a moštů, v nichž pektin způsobuje nepř́jemné rosolovatění. Dosud však zůstává nedořešený problém tvorby sedimentu kyseliny pektinové, který není enzymem napaden. Nicméně se těchto preparátủ běžně užívá a poktolytickým enzymưm je věnována velká pozornost $[35,36,37,38,43]$. Zdrojem může být i Penicillium notatum a Penitlilium chrysogenum $[39,40]$.

\footnotetext{
*) První cást byla otisknuta $\mathrm{v}$ Kvasném průmyslu 1
(1955), 83
}

V obchodě jsou četné preparáty (Pektinol, Polyzym, Oryzym, Pektosin, Filtrazym, Pektozym, Pectoclarol) různých vlastností a upravené $\mathrm{k}$ rưzným účelům. $\mathrm{V}$ roce 1954 byl $\mathrm{v}$ Bulharsku připraven práškový enzymový preparát Bystrin.

Poměrně málo zpráv je o mikrobiálních lipázách. Některé patenty uvádějí př́pravu lipolytických preparátů na obilných substrátech $\mathrm{z}$ různých aspergilů [26] které se zdají i podle našich výsledkủ neivhodnějšími producenty. Lipázových preparáti̊ lze použít všude, kde nelze provést zmýdelnění tuku chemicky (na př. př̀i koncentrování olejových roztokủ některých vitaminů), ale též při výrobě sýrů, vydělávání koží a j. [24, 25]. Také bakteriální lipázy mohou najít uplatnění $\mathrm{v}$ technickém použití. Vynikajícím producentem je rod Pseudomonas. Někteří zástupci tohoto rodu dosahují maximální produkce lipáz za značně vysokých teplot (až $75^{\circ} \mathrm{C}$ ): při nižších teplotách $\left(30^{\circ}\right)$ je tvorba zastavena, ačkoli růst je dabrý [47].

Větší zájem byl $\mathrm{v}$ poslední době projeven o celulázy. Jsou produkovány jak bakteriemi, tak houbami. Kultivovali jsme submersně celulolytické bakterie zvl. Sporocytophaga myxococcoides a získali metabolické tekutiny se zrretelnou aktivitou, celuláz. Chromatograficky jsme shledali jako meziprodukt odbourávání celulosy i karboxymethylcelulosy, celobiosu, která je dále štěpena na glukosu. Podobně význačnou aktivitu měly i naše kmeny Aspergilus oryzae a některé vyšší houby patřící mezi Basidiomycetes, které produkovaly tento enzymový systéni za submersních podmínek [63]: Množi se zprávy o význačných producentech celuláż $[18,19,20,21$, 52]. Také Aspergilus oryzae vykazuje celulolytiekou aktivitu $[22,23]$.

Je třeba. se zmínit i o dextransacharáze, enzy mu, který vylučuje do prostředí . Leuconostoc mesenteroides. Tento enzym odštěpuje z molekuly sacharosy fruktosu a z glukosylových zbytků synthesuje polysacharid dextran, známou ¿náhradu krevního plasmatu. Dextransacharáza múže být oddělena od buněk, aniž je tím pozměněna její synthetická aktivitá, což má dalekosáhlé výhody pro výrobu dextranu hlavně prìi jeho čištění a preparaci k farmaceutickému použití. Aby se dosáhlo vytváření dextranu jen $\mathrm{v}$ určité vhođné molekulové váze; stači přidat do reagující směsi malé množství již hotového dextranu žádaných vlastností [55]. Byl též patentován obdobný způsob, užívající celulosních bakterii Cellvibrio fulva [56].

Era antibiotik přinesla potřebu jejich analytickéhơ stanovení. $\mathrm{V}$ prrípadě penicilinu koná služby bakteriální penicilináza (z B. cereus a B. subtilis), přeměňující penicilin na kyselinu penicilinoyou. Na základě jejího účinku byla vypracována rychlá metoda stanovení penicilinu. Penicilináza se vyrábí submersně, precipituje se organickými srážedly a dává se na trh jako suchý enzymový koncentrát se standardní aktivitou $[32,33]$. Od roku 1951 soustřed'uji na sebe zájem farmaceutického průmyslu dva enzymy, streptokináza a streptodornáza, produkované hemolytickými streptokoky a užívané $\mathrm{k}$ odstranění nekrotic- 
kých tkání nebo pyogenních membrán na ranách a spáleninách, při čemž zdravá tkáň není napadena $[13,14,15,16,66]$.

Některé enzymy nejsou uvolňovány mikroorganismem do prostředí $\mathrm{v}$ podstatném množství a jsou proto extrahovány prímo $\mathrm{z}$ buněk. Tohoto typu jsou především invertáza, laktáza, kataláza, glukosooxydáza a j. Buňky produkčních mikrobů jsou destruovány, extrahovány vhodným rozpouštědlem a enzym je z roztoku vysrážen. Invertáza může být získána i z autolysovaných kvasnic pod toluenem a vysrážena alkoholem. Kataláza se vyrábí ze submersně pěstovaných plísní a bakterií a užívá se jí $\mathrm{k}$ některým speciálním účelům všude, kde je třeba odstranit peroxyd vodíku. Glukosooxydáza, známá též pod jménem notatin, je získávána bud' z mycelia penicilií produkujících penicilin, nebo z kultur Aspergilus niger. Jejím účinkem je glukosa oxydována na kyselinu glukonovou a vznikající $\mathrm{H}_{2} \mathrm{O}_{2}$ je zneškodněn katalázou. $\mathrm{V}$ průmyslovém měřítku se užívá glukosooxydázy k odstranění glukosy $\mathrm{z}$ vajec, určených $\mathrm{k}$ sušení. Glukosa ve vejcích i po vysušení reaguje $\mathrm{s}$ fosfolipidy (kefalin) a dává produktu nepř́ijemnou chut' i barvu a tak omezuje skladovací dobu hotového výrobku $[10,11,12,30,50]$. Glukosooxydáza se osvědčila i při stabilisaci ovocných vín [61] a při analytickém stanovení glukosy vedle jiných redukujících cukrů ve fermentačních tekutinách, syrupech a pod. [62]. Byl ohlášen i patent, užívající glukosooxydázy $\mathrm{k}$ př́pravě kyseliny glukonové $\mathrm{z}$ glukosy [51].

Reaguje-li tento enzymový systém (glukosooxydáza + kataláza) s přebytkem glukosy $\mathrm{v}$ uzavřeném prostoru, jako je na príklad láhev piva, ovocného syrupu nebo kompotová konserva, je vyčerpán téměr veškerý kyslík jak $\mathrm{z}$ roztoku, tak i z prostoru vyplněného vzduchem. Tak lze zabránit nevítaným změnám chuti, způsobeným oxydací.

$\mathrm{Z}$ dalších enzymů by bylo třeba se zmínit alespoň o ureáze, kterou lze získat $\mathrm{z}$ některých mikrobủ [46, 67], o fosfatázách a sulfatázách [44, 45], hyaluronidáze čili hyáze, užívané v lékařství, lysozymu, rozpouštějícím za živa některé bakterie [61], acylázách, štěpících acylderiváty směsi D- a L-aminokyselin na čisté L-aminokyseliny a D-acylaminokyseliny, takže je lze dále oddělit [27] a o řadě dalších enzymů, právě tak jako o dalších možnostech aplikace mikrobiálních enzymů na príklad ve farmacii $[28,29]$. Tak na příklad glukuronidáza (ketodáza) se používá $k$ odštěpení glukuronidových zbytků z komplexních ketosteroidů $[60]$.

Zajímavou práci uveřejnil Simpson [68], který použil pentosanázy při výrobě pšeniěného škrobu a zvýšil výnos ze 60 na $90 \%$.

Ưcèem tohoto referátu však není ukázat všechny a zvlášt teoretické možnosti použití mikrobiálních enzymů. Jeho snahou je podat přehled celé šírky problému a zejména zvýšit zájem o tento obor, spadající především do kvasného, ale i do farmaceutického a potravinářského průmyslu, obor, který je nyní ve stadiu počátečního růstu a vývoje a který v blízké budoucnosti nepochybně přinese další překvapení. Bylo by žádoucí, aby výrobě i výzkumu průmyslových enzymů byly u nás umožněny poloprovozni zkoušky, založené na důkladném výzkumu laboratorním. Náš průmysl, jinak jistě velmi pokročilý, má zde co dohánět. Jestliže kapitalistické státy jako USA, Velká Britanie a jiné vyráběji již po celá desetiletí bohatou škálu technických enzymových preparátů i čištěných enzymů mikrobiálního pưvodu, jistě tak nečini se ztrátou. Př́ikladem nám múže být i Bulharsko, které před nedávnem začalo vyrábět „,bystrin“. V SSSR je ostatně vyráběna řada enzymových preparátů a máme zprávy, že jejich výzkumu je věnována značná energie [59]. Ostatně i dosavadní úspěchy našich pracovníků $\mathrm{v}$ oboru plísňových amyláz mohou zde být význačnou pobídkou.

\section{Literatura}

[1] Dion W. M., Can. J. Research C 28 (1950), 577.

[2] Dion W. M., Can. J. Research C 28 (1950), 586.

[3] Lulla B. S., Research 3 (1950), 581.

[4] Lulla B. S., Bioch. Biophys. Acta 7 (1951), 244

[5] Dingle J., Solomons G. L., J. Appl. Chem. 2 (1952), 395.

[6] Dworschack R. G. a sp., Arch. Bioch. B ophys. 41 (1953), 48.

[7] Maxwell M. E., Australian J. Appl. Sci. 1 (1950), 348.

[8] Crewther W. G., Lennox F. G., Nature 165 (1950), 680.

(9) Yuki J. Repts. Inst. Chem. Research, Kyoto Univ. 19 (1950), 103 (Chem. Abstr. 45 [1951] 5198a).

[10] Anonym., Agr. Food Chem. 1 (1953), 194.

[11] Anonym., Chem. Eng. News 31 (1953), 772.

[12] Anonym., Chem. Week 72 (1953), 88.

[13] Bernheimer A. W., Trans. N. Y. Acad. Sci. (Ser. II), 14 (1952), 137.

[14] Anonym., Chem. Week 68 (1951), 22.

[15] Anonym., Chem. Week 68 (1951), 29.

[16] Eltiot S. D., Trans. N. Y. Acad. Sci. (Ser. II), 14 (1952), 137.

[17] Sherry S. Trans. N. Y. Acad. Sci. (Ser. II), 14 (1952), 138.

[18] Saunders R. R. a sp., J. B ol. Chem. 174 (1948), 697.

[19] Whitaker D. R., Science 116 (1952), 90.

[20] Reese E. T. a sp., Physiol. Plantarum 5 (1952), 379.

[21] Reese E. T., Levinson H. S., Physiol. Plantarum 5 (1952), 345.

[22] Jermyn M. A., Australian J. Sci. Res. 5 B (1952), 409.

[23] Jermyn M. A., Australian J. Sci. Res. 5 B (1952), 433.

[24] Ramakrishnan C. V., Science 113 (1951), 125.

[25] Ramakrishnan. C. V., Experientia 7 (1951), 434.

[26] Smythe C. V., Drake B. B., U. S. Pat. 2480090 (1919).

[27] Neuberg C., Mandl J., Enzymologia 14 (1950), 128.

[28] Bersin T., Südd. Apoth. Zeitg., 90 (1950), 801.

[29] Schenck G., Deutsch. Apoth. Ztg. 25 (1953), 445.

[30] Loesecke H. W. von, Agr. Food Chem. 1 (1953), 794.

[31] Webb M., J. Gen. Microbiol. 2 (1948), 260.

[32] Kato K., J. Antibiot. Japan 5 (1952), 631

[53] Pollock M. R., Brit. J. Exp. Pathol. 34 (1953), 251.

[34] Brockaja S. Z., Mikrobıologije 23 (1954), 153.

r35] Wood R. K. S., Natire 167 (1951), 771 .

[36] White L. S., Fabian F. W., Appl. Microbiol. 1 (1953), 243.

137] Schubert E., Nature 169 (1952), 131.

[38] Schubert E. Arch. Biochem.- Biophys. 38 (1952), 78.

[39] Phaff H. J., Arch. 'Biochem. 15 (1947), 67.

[40] Lulla B. S., Johar D. S., Cirrent Sci. 22 (1953), 79.

[41] Lineweaver H., Jansen E. F., Adv. Enzymol. 11 (1951), 267.

[42] Kertész Z. J., The Pectic Substances, N. York (1951)

[43] Gaponenkov T. K., Mikrobiologija 23 (1954), 317.

[44] Povolocka:a K. L., Skorobogatova E. P., Biochimija 12 (1947), 268.

[45] Howell A. Jr., Fitzgerald R. J. J. Bact. 66 (1953), 437.

[46] Larson A. D., Kallio R. E., J. Bact. 68 (1954), 67.

[47] Nashif S. A., Nelson F. E., J. Dairy Sci. 36 (1953), 459, 471, 698.

[48] Tytell A. A. a sp., Feder. Proc. 13 (1954), 312.

[49] Goldsmith M. T., Textile Res. J. 20 (1950), 613.

[501 Baldwin R. R. a sp., Food Technol. 7 (1953), 275.

[51] Baker D. L., U. S. Pat. 2651592 (1953).

[52] Siu R. G. H. Reese E. T., Botan. Rev. 19 (1953), 377.

[53] Matsushima K., Ferment. Technol. Japan 31 (1953), 367, $387,389$.

[54] Matsushima K., Ferment. Technol. Japan 32 (1954), 14.

[55] Tsuchiya H. M., Chem. Eng. News 31 (1953), 3960.

[56] Anonym., Brit. Pat. 675025 a 675085 (19£2).

[57] Damodaran M. a sp., Bioch. Biophys. Acta 17 (1955), 99.

[58] Grutter F. H., J. Bact. 69 (1955), 728.

[59] Komarova L. I., Mikrobiologija 24 (1955), 646.

[60] Warner-Chilcott Labs., inserát, N. York (1955).

[61] Yang H. Y., Food Res. 20 (1955), 42.

[62) Damodaran M., Singh K. J. Sci. and Ind. Res. (India) 13B (1954), 419.

[63] Stärka J., Č. mykologie 9 (1955), 97.

[64] Stârka J., Kvasný prưmysl 2 (1956), 83.

[65] Hoogerheide J. C. v Industrial Fermentations, vol. 2. N. York (1954).

[66] Pakula R. a sp., Med. Doświadcz. i Mikrobiol. 6 (1954), 335.

[67] Larson A. D., Kallio R. R., J. Bact. 68 (1954), 67.

[68] Simpson F, J., Bact, Proceedings 24 (1954). 